\title{
Effect of dead phytoplankton cells on the apparent efficiency of photosystem II
}

\author{
Daniel J. Franklin ${ }^{1, *}$, Chang Jae Choi ${ }^{2}$, Claire Hughes ${ }^{1}$, Gill Malin ${ }^{1}$, John A. Berges ${ }^{2}$ \\ ${ }^{1}$ School of Environmental Sciences, University of East Anglia, Norwich, Norfolk NR4 7TJ, UK \\ ${ }^{2}$ Department of Biological Sciences, University of Wisconsin-Milwaukee, PO Box 413, Milwaukee, Wisconsin 53201, USA
}

\begin{abstract}
Measurements of the efficiency of photosystem (PS) II have become widespread in biological oceanography, and various forms are used to assess the 'health' of marine phytoplankton and to help estimate primary productivity. Absolute values of PS II efficiency depend to some extent on the measuring system, but changes in PS II efficiency are most commonly interpreted in terms of cellular acclimations to changing irradiance (including photoacclimation and photoinhibition) and nutrient availability (especially $\mathrm{N}$ and $\mathrm{Fe}$ ). Recent measurements of phytoplankton viability in the surface ocean have revealed that in many regions phytoplankton assemblages may contain large proportions of dead cells. The effect of these dead cells on apparent PS II efficiency is largely unknown. By mixing live and dead cells and measuring PS II efficiency, we show that the presence of photosynthetically non-functional (dead) cells has surprisingly little effect; in a number of species, mixtures in which $50 \%$ of the cells were dead had values of 0.5 , similar to values often found in natural assemblages. A simple model indicates that the non-linear nature of the fluorescence ratio is responsible for this unexpected result. We conclude that relatively high values of PS II efficiency cannot be used as evidence of low mortality. Our findings highlight the need for more information on the physiological status of both eukaryotic and prokaryotic microalgae in nature.
\end{abstract}

KEY WORDS: Chlorophyll fluorescence $\cdot$ Fluorometry $\cdot$ Primary production $\cdot$ Viability $\cdot$ Cell stains · Productivity

Resale or republication not permitted without written consent of the publisher

\section{INTRODUCTION}

Oceanic net primary production (NPP) is a critical parameter in understanding the global ocean, but is difficult to measure synoptically. Typically, NPP is calculated from surface chlorophyll a concentration (chl a), determined using satellite-based optical sensors (Behrenfeld et al. 2005). Such methods depend on 'sea-truthing' for which in situ chlorophyll fluorometry, involving measurements of the efficiency of photosystem (PS) II, has been an important tool to help understand how to convert chl $a$ to NPP and to reveal spatial and temporal variability in photosynthetic production. Within an appropriate theoretical framework, chlorophyll fluorescence methods can be used to predict photosynthetic rates (Kolber \& Falkowski 1993, Suggett et al. 2004). There are several different methods for measuring chlorophyll fluorescence (see Table 1), and a wealth of parameters that can be derived (Kromkamp \& Forster 2003). A commonlyused and robust parameter is the ratio of variable to maximum chlorophyll fluorescence made under darkacclimated conditions $\left(F_{\mathrm{V}} / F_{\mathrm{M}}\right) \cdot F_{\mathrm{V}} / F_{\mathrm{M}}$ is a measure of the capacity for noncyclic photosynthetic electron flow in cells, and is affected by light, nutrients and other environmental factors (Cullen \& Davis 2003). Thus, changes in $F_{\mathrm{V}} / F_{\mathrm{M}}$ are thought to reflect the 'photosynthetic health' of the phytoplankton community, and to be affected mainly by cellular acclimations to changing abiotic conditions.

A basic assumption in fluorescence methods is that the chl a detected represents physiologically competent (i.e. living) cells. Many biological oceanographers assume that dead cells are rapidly lost from surface waters by sinking, grazing, or by bacterial decomposition (Berges \& Falkowski 1998) and high community PS II efficiency values are taken as reflecting acclimation across the entire phytoplankton community 
Table 1. Phytoplankton photosystem II efficiency from a variety of ocean provinces and its interpretation. FRRf = fast repetition rate fluorometry, $\mathrm{PP}$ = pump and probe fluorometry, $\mathrm{PAM}=$ pulse amplitude modulated fluorometry

\begin{tabular}{|c|c|c|c|c|}
\hline Location & Phytoplankton type & $\begin{array}{l}\text { Photosynthetic capacity, } \\
\text { range and conclusions }\end{array}$ & $\begin{array}{l}\text { Active fluorescence } \\
\text { method }\end{array}$ & Source \\
\hline $\begin{array}{l}\text { Tropical and } \\
\text { South Pacific }\end{array}$ & $\begin{array}{l}\text { Prochlorococcus sp. } \\
\text { and Synechococcus sp. }\end{array}$ & $\begin{array}{l}0.2 \text { to } 0.5, \text { nutrient } \\
(\mathrm{Fe}) \text { limitation }\end{array}$ & FRRf & $\begin{array}{l}\text { Behrenfeld et al. (2006), } \\
\text { Behrenfeld \& Kolber (1999) }\end{array}$ \\
\hline $\begin{array}{l}\text { Eastern } \\
\text { equatorial Pacific }\end{array}$ & $\begin{array}{l}\text { Natural phytoplankton } \\
\text { populations }\end{array}$ & $\begin{array}{l}0.2 \text { to } 0.5, \text { nutrient } \\
(\mathrm{Fe}) \text { limitation }\end{array}$ & FRRf & Greene et al. (1994) \\
\hline Eastern Pacific & $\begin{array}{l}\text { Photosynthetic bacteria } \\
\text { and phytoplankton }\end{array}$ & $\begin{array}{l}0.6 \text { for phototrophic bacteria; } \\
0.1 \text { to } 0.5 \text { for phytoplankton; } \\
\text { variation due to photoinhibition, } \\
\text { cell division and the respiratory } \\
\text { reduction of the plastoquinone poo }\end{array}$ & pol & Kolber et al. (2000) \\
\hline North Atlantic & $\begin{array}{l}\text { Natural phytoplankton } \\
\text { populations }\end{array}$ & $\begin{array}{l}0.2 \text { to } 0.55 \text {, variations driven } \\
\text { by horizontal advection, not } \\
\text { nitrate concentration }\end{array}$ & PP & Olaizola et al. (1996) \\
\hline $\begin{array}{l}\text { Northeast } \\
\text { Atlantic }\end{array}$ & $\begin{array}{l}\text { Natural phytoplankton } \\
\text { populations }\end{array}$ & $\begin{array}{l}0.3 \text { to } 0.6 \text {, low at the surface } \\
\text { and higher at depth }\end{array}$ & PP & Boyd et al. (1997) \\
\hline Southern Ocean & $\begin{array}{l}\text { Pico-, nano-, and } \\
\text { microphytoplankton }\end{array}$ & $\begin{array}{l}0.3 \text { to } 0.55 \text {, nutrient } \\
(\mathrm{Fe}) \text { limitation }\end{array}$ & FRRf \& PAM & Gervais et al. (2002) \\
\hline Arctic Ocean & $\begin{array}{l}\text { Sea-ice microalgal } \\
\text { communities } \\
\text { (mainly Phaeocystis) }\end{array}$ & $\begin{array}{l}0.1 \text { to } 0.65 \text {, 'unhealthy } \\
\text { to healthy'; a function of } \\
\text { salinity, light and nutrients }\end{array}$ & PAM & McMinn \& Hesgeth (2004) \\
\hline North Sea & $\begin{array}{l}\text { Microphytobenthic } \\
\text { algae }\end{array}$ & $\begin{array}{l}0.4 \text { to } 0.73 \text {, variation driven } \\
\text { by irradiance }\end{array}$ & PAM & Hartig et al. (1998) \\
\hline Gulf of Mexico & Diatom Ethmodiscus & 0.2 to 0.6 , diel variation & PAM & Villareal (2004) \\
\hline
\end{tabular}

(Table 1). However, recent field studies indicate that phytoplankton communities can contain large proportions of dead cells, and that these dead cells can, at times, be the most abundant fraction in surface waters (van Boekel et al. 1992, Hayakawa et al. 2008). Such conclusions come from combinations of cell-based viability staining and enzyme assays, which show that the majority of the eukaryotic microalgal assemblage can persist as dead, pigment-containing cells (Veldhuis et al. 2001). In the oligotrophic central Atlantic, cyanobacterial populations also show large proportions (>50\%) of intact, but dead cells (Agustí 2004).

The potential impact of these dead cells on estimates of NPP and PS II efficiency measurements is unclear: whilst PS II efficiency clearly responds to nutrient limitation in cultures and in natural communities, the effect of dead cells on PS II efficiency has not been explicitly tested under laboratory conditions. Some field measurements suggest that where abiotic conditions change suddenly, for example at the mouth of an estuary, mass microalgal mortality can be accompanied by a relatively constant PS II efficiency (Dijkman \& Kromkamp 2006) which suggests that PS II efficiency may be insensitive to physiological condition. The use of chlorophyll fluorescence as a precise physiological indicator in field assemblages was also questioned by Cullen \& Renger (1979) who introduced the concept of 'inactive fluorescence' and its potential to colour the interpretation of fluorescence ratios. Given the growing realisation of the presence of dead phytoplankton cells in surface waters, and the importance of surface water chlorophyll to NPP calculation, we examined the effect of dead cells on apparent PS II efficiency.

\section{MATERIALS AND METHODS}

Triplicate batch cultures of the marine eukaryotic microalgae Thalassiosira pseudonana (CCMP 1335), Emiliania huxleyi (CCMP 1516), Amphidinium carterae (CCMP 1314) and Dunaliella tertiolecta (CCMP 364), and the freshwater Chlamydomonas reinhardtii (UTCC84) were grown in borosilicate flasks in ESAW medium, or for the chlorophytes, ASW or DY-V medium. Eukaryotic cells were grown at an irradiance of approximately $115 \mu \mathrm{mol}$ photons $\mathrm{m}^{-2} \mathrm{~s}^{-1}$. The cyanobacterium Prochlorococcus (CCMP 2389) was grown in Pro99 medium (for all media recipes see Anderson 2005) at an irradiance of $25 \mu \mathrm{mol}$ photons $\mathrm{m}^{-2} \mathrm{~s}^{-1}$. Eukaryote culture growth was assessed by using a Coulter Multisizer 3 (Beckman Coulter) and raw fluorescence. The efficiency of PS II was assessed with a Phyto-PAM (Walz), or via DCMU-poisoning of 
PS II and a Turner designs fluorometer (Geider et al. 1993). We did not dark-adapt cells as preliminary observations indicated that under our culture conditions, non dark-adapted PS II yield was not significantly different from the maximum/dark-adapted yield. Therefore, our PS II yield measurements are of the form $F_{\mathrm{V}}{ }^{\prime} / F_{\mathrm{M}}$ ' (Sagert et al. 1997) which will not be identical to $F_{\mathrm{V}} / F_{\mathrm{M}}$, but instead will be intermediate between $\Delta F / F_{\mathrm{M}^{\prime}}$ (yield at experimental irradiance sensu Kromkamp \& Forster 2003) and $F_{\mathrm{V}} / F_{\mathrm{M}}$ (yield after complete dark-adaptation). $F_{\mathrm{V}}{ }^{\prime} / F_{\mathrm{M}}{ }^{\prime}$ indicates the efficiency of open PS II reaction centres. Cell-free controls $(0.2 \mu \mathrm{m}$ filtered) showed no soluble fluorescence (sensu Cullen \& Davis 1993) in either live or dead treatments. Prochlorococcus growth was assessed by flow cytometry (BD Biosciences FACScalibur). In mid-log phase, nutrient-replete cells were harvested and then killed by exposure to heat $\left(80^{\circ} \mathrm{C}\right.$, $5 \mathrm{~min})$, cooled to growth temperature, and then mixed with live cells. The heat-killing treatment caused $100 \%$ mortality as assessed by staining with SYTOX-green $(5 \mu \mathrm{M}$ final concentration) or $1 \%$ Evan's blue solution (applied at $50 \mu \mathrm{l} \mathrm{ml}^{-1}$ ) and inspection with epifluorescent or light microscopy (Crippen \& Perrier 1974, Veldhuis et al. 1997). The viability of heat-killed cells was also checked by inspection of treated cultures; the absence of regrowth, and cell loss over the following days, further supported a total loss of viability. Dead cells (D) were recounted after the killing-treatment and then mixed with live cells (L) from the source culture in the following proportions: 0D:100L，25D:75L，50D:50L, 75D:25L, and 100D:0L. 'Initial fluorescence', i.e. the fluorescence of mixtures of live and dead cells, not under experimental irradiance due to the need to manipulate the cells in the laboratory, here refered to as $F_{0}{ }^{\prime}$; and $F_{\mathrm{V}}{ }^{\prime} / F_{\mathrm{M}}{ }^{\prime}$ (see above) were plotted as a function of dead cell concentration.

\section{RESULTS AND DISCUSSION}

We used a suite of species representing most of the major phytoplankton taxa and found that the pattern of decline in PS II efficiency with cell death was common to all species. Heat-killed cells were intact and retained chlorophyll, though initial fluorescence was reduced by up to a maximum of $80 \%$ (Fig. 1). In mixtures containing $0 \%$ dead cells $F_{\mathrm{V}}{ }^{\prime} / F_{\mathrm{M}}{ }^{\prime}$ ranged from 0.68 (Prochlorococcus) to 0.39 (Amphidinium carterae); all other species had a $F_{\mathrm{V}^{\prime}} / F_{\mathrm{M}^{\prime}}>0.54$. In heat-killed suspensions ( $100 \%$ dead cells) $F_{\mathrm{V}}{ }^{\prime} / F_{\mathrm{M}}{ }^{\prime}$ was 0 in all species. Surprisingly, $F_{\mathrm{V}}{ }^{\prime} / F_{\mathrm{M}}$ ' was relatively insensitive to the proportion of dead cells present in the mixture; $25 \%$ dead cells reduced $F_{\mathrm{V}}{ }^{\prime} / F_{\mathrm{M}}{ }^{\prime}$ by only $5 \%$, and when half the cells were dead, the decline in $F_{\mathrm{V}}{ }^{\prime} / F_{\mathrm{M}}{ }^{\prime}$ was typically less than $20 \%$ (Fig. 1). This pattern is due to 'dead cell chlorophyll' contributing to the instrumental reading of $F_{0}$ in live/dead mixtures, but not $F_{\mathrm{M}}$, since dead cells have zero 'active' or 'variable' fluorescence (i.e. $F_{\mathrm{M}}-F_{0}$, or $F_{\mathrm{V}}$ ). The overall effect is that the decline in the ratio of $F_{\mathrm{V}} / F_{\mathrm{M}}$ ' is slight until a relatively high proportion of dead cells are present in the mixture (Fig. 1). This result seems surprising, but a simple model helps to clarify the effects. If we assume that all cells have a constant $F_{0}$, and that live cells have the capacity for variable fluorescence which results in a $F_{M}$

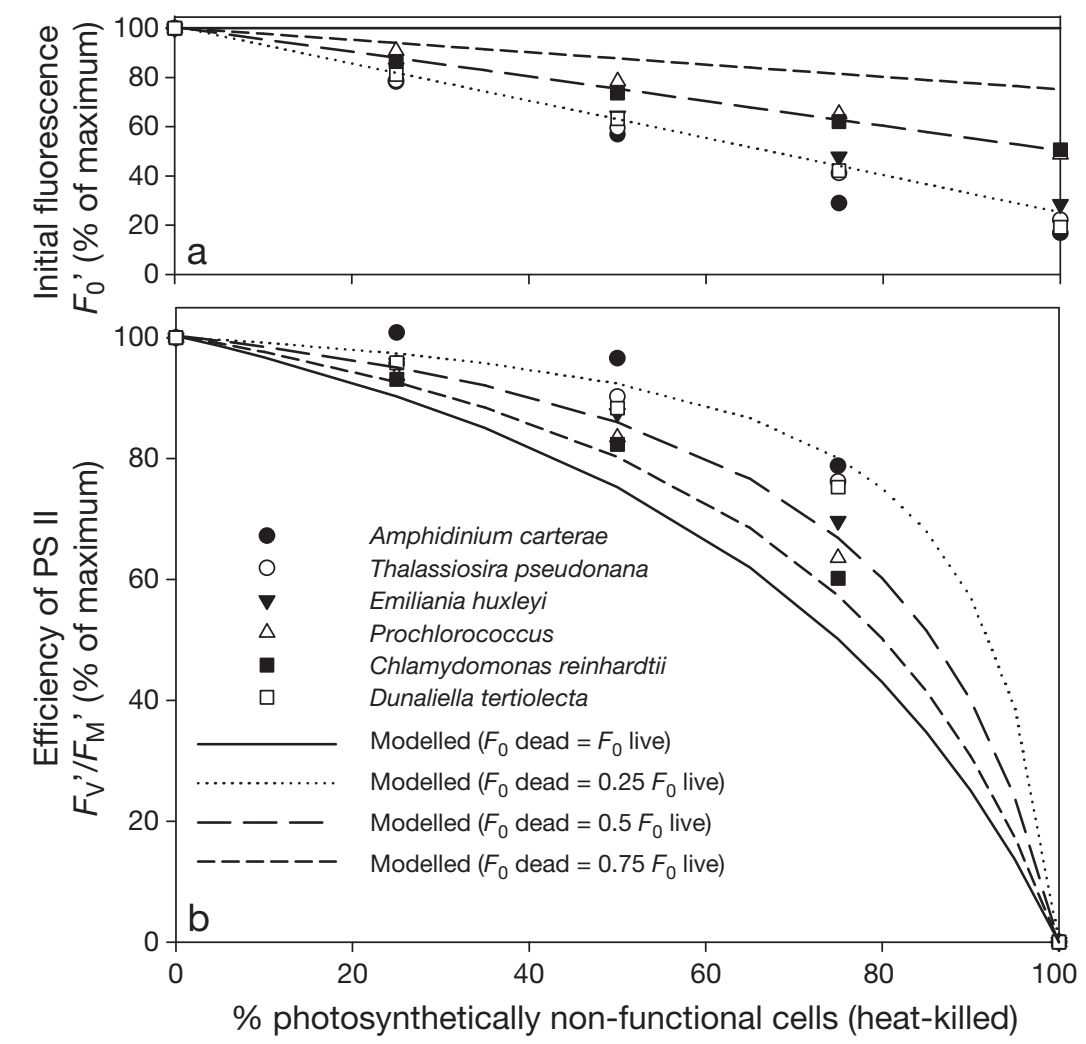

Fig. 1. Effect of photosynthetically non-functional (dead) cells on the initial fluorescence $\left(F_{0}^{\prime}\right)$ and efficiency of PS II $\left(F_{\mathrm{V}}{ }^{\prime} / F_{\mathrm{M}}\right.$ '; see 'Materials and methods'). Cells from triplicate batch cultures were killed with heat $\left(80^{\circ} \mathrm{C}, 5 \mathrm{~min}\right)$, cooled to growth temperature and then mixed with untreated cells. (a) Decline in initial fluorescence $\left(F_{0}\right)$. (b) Decline in the efficiency of PS II $\left(F_{\mathrm{V}}{ }^{\prime} / F_{\mathrm{M}}{ }^{\prime}\right)$, as a function of the proportion of photosynthetically non-functional (dead) cells in the mixture. $F_{\mathrm{V}}{ }^{\prime} / F_{\mathrm{M}}$ ' ranged from 0.67 ( $0 \%$ dead cells in Prochlorococcus) to 0 (all $100 \%$ dead mixtures). Lines indicate the modelled declines that result from assumed changes in fluorescence due to mortality (see 'Results and discussion') 
equal to $F_{0} \times 3$ (i.e. parameters that would give an $F_{\mathrm{V}} / F_{\mathrm{M}}$ of 0.66 ), and that dead cells have no capacity for $F_{\mathrm{V}}$ such that $F_{\mathrm{M}}=F_{0}$, then we can calculate the effect of dead cells on $F_{\mathrm{V}} / F_{\mathrm{M}}$ in live/dead mixtures. Such assumptions result in the solid 'modelled' lines of Fig. 1. Further, if we specify that $F_{0}$ falls by a constant proportion in dead cells $\left(0.25,0.5\right.$, and 0.75 of the $F_{0}$ of live cells; Fig. 1), we are able to reproduce the experimental results almost exactly. This simple model emphasizes that the $F_{\mathrm{V}} / F_{\mathrm{M}}$ ratio is decidedly non-linear, and confirms that our results are not, in fact, unexpected. Thus, these data clearly show that high values of $F_{\mathrm{V}} / F_{\mathrm{M}}$ are not of themselves evidence against the presence of dead cells in natural ecosystems.

If surface waters contain a large fraction of dead autotrophic biomass (Veldhuis et al. 2001, Agustí 2004, Hayakawa et al. 2008) then significant misinterpretations of PS II efficiency data are possible. For example, high values (see Table 1) could indicate modest nutrient limitation of living cells, but they are also consistent with the presence of a large fraction of dead (or perhaps quiescent) cells. The presence of metabolically-inactive cells could explain the strong uncoupling between primary production and chl a biomass in the subtropical gyres (Marañón et al. 2003). Marañón et al. (2003) demonstrated that the photosynthetic response of quiescent cyanobacterial cells to episodic nutrient inputs is the dominant factor in uncoupling chl a biomass and primary production. The role of quiescence in the lifehistory of eukaryotic microalgae is less clear, but indirect evidence, such as the speed at which eukaryotic microalgae respond to changed nutrient conditions both in biomass and diversity, suggests that persistent 'seed' populations could be significant components of the eukaryotic phytoplankton. Seeding from benthic resting stages is well-accepted, especially for diatoms, but the importance and possible persistence of such stages in the oceanic realm is much less clear. Diatom resting stages have chlorophyll (Doucette \& Fryxell 1983), indicating the potential for uncoupling between chlorophyll biomass and primary production in eukaryotic as well as prokaryotic microalgae. Other possible cell fates include death due to pathogen attack and zooplankton grazing, both of which likely result in rapid cell lysis or removal and therefore quickly reduce biomass. In contrast, the cell death induced by environmental stress may result in a greater persistence of dead cells, and further contribute to the uncoupling of chl a biomass and primary production in oceanic systems. In addition to sinking and grazing, a third major fate for phytoplankton production has been mooted (Bidle \& Falkowski 2004, Franklin et al. 2006) namely natural cell death, which can be induced by the oxidative stress that accompanies high irradiance. Such a cell death pathway appears to be particularly significant for cyanobacteria (Llabares \& Agustí 2006) which are responsible for a large fraction of marine primary production (Falkowski et al. 1998).

An obvious question arising from this work is whether using heat-killed cells in our live/dead mixtures is a realistic representation of dead cells in nature. Heat-killed cells have a shrunken appearance, with cytoplasmic bunching and reduced chlorophyll fluorescence. These characteristics are similar to the 'senescent' appearance of microalgae in nutrientexhausted batch cultures, which are also called 'chlorotic' cells (La Roche et al. 1993, Franklin \& Berges 2004). Therefore, heat-killed cells may offer a reasonable physical simulation of natural dead cells, if one accepts that natural cell death in nature is caused primarily by nutrient starvation and results in the chlorotic state. It appears likely that a combination of high irradiance and low nutrients is often a cause of phytoplankton cell death in nature; the cyanobacterium Trichodesmium, for example, undergoes mass cell death in response to this type of environmental stress, and in addition, Trichodesmium cell death appears to be 'programmed' (Berman-Frank et al. 2004). We have also experimented with other methods of generating dead cells for these experiments, such as killing with chemicals $\left(\mathrm{H}_{2} \mathrm{O}_{2}, \mathrm{NaNO}_{2}\right.$ and formaldehyde) and also with light and nutrient deprivation. Results were broadly similar, though carry-over of toxins in mixtures are a problem in the former case, and low numbers of surviving cells and cell detritus in the latter cases make a 'clean' test difficult.

Lastly, our data have implications for understanding the increased community PS II efficiency which occurs after nutrient (e.g. iron) enrichment during large-scale field studies. In the Eisenex study, PS II efficiency increased from 0.3 to around 0.55 due to iron enrichment of a patch of the Southern Ocean. The main consequence of supplying iron was to increase the chl a biomass and primary productivity of the microphytoplankton, however, the increase in primary productivity soon (after $2 \mathrm{wk}$ ) became uncoupled from chl a biomass, and this uncoupling was attributed to physical variability in the upper water column (Gervais et al. 2002). Although we have shown that high apparent PS II efficiency is possible even when a large fraction of the autotrophic biomass is photosynthetically nonfunctional, increases in PS II efficiency due to micronutrient enrichment must represent an increase in the rate of Fe-dependent synthesis of PS II units since they correlate with increased chl a biomass (Gervais et al. 2002). Our data shows that an increase in PS II efficiency of 0.25 can correspond to an increase of $50 \%$ in the number of viable cells. By measuring phytoplankton physiological state, and biomass, before, during and after nutrient enrichment, it should be possible to 
learn if the change in PS II efficiency involves the selection, and subsequent division, of the viable fraction in previously heterogenous populations. As has been shown for bacterioplankton, it is currently exceedingly difficult to encapsulate all the metabolic heterogeneity that exists within microbial populations with single-stain techniques (Pirker et al. 2005). In the bacterioplankton literature, the presence of metabolically-inactive cells is much better appreciated, with 0.1 to $99 \%$ of cells recognised as 'inactive' or 'dead' depending on the sample and assessment method (Pirker et al. 2005). Viability and quiescence are unappreciated, yet fundamental, properties of phytoplankton cells which will likely effect important biogeochemical reactions. Thus, flow cytometric work to characterise the metabolic diversity of natural phytoplankton assemblages, in conjunction with laboratory validation of staining techniques, appears an attractive priority for research.

Acknowledgements. We thank the editor and reviewers for improving the manuscript and the Natural Environment Research Council (UK) for financial support (NE/E003974/1).

\section{LITERATURE CITED}

Agustí S (2004) Viability and niche segregation of Prochlorococcus and Synechococcus cells across the Central Atlantic Ocean. Aquat Microb Ecol 36:53-59

Anderson RA (2005) Algal culturing techniques. Elsevier, Amsterdam

Behrenfeld MJ, Kolber ZS (1999) Widespread iron limitation of phytoplankton in the South Pacific Ocean. Science 283:840-843

Behrenfeld MJ, Boss E, Siegel DA, Shea DM (2005) Carbonbased ocean productivity and phytoplankton physiology from space. Global Biogeochem Cycles 19:GB1006, doi: 10.1029/2004GB002299

Behrenfeld MJ, Worthington K, Sherell RM, Chavez FP, Strutton P, McPhaden M, Shea DM (2006) Controls on tropical Pacific Ocean productivity revealed through nutrient stress diagnostics. Nature 442:1025-1028

Berges JA, Falkowski PG (1998) Physiological stress and cell death in marine phytoplankton: induction of proteases in response to nitrogen or light limitation. Limnol Oceanogr 43:129-135

Berman-Frank I, Bidle KD, Haramaty L, Falkowski PG (2004) The demise of the marine cyanobacterium, Trichodesmium spp., via an autocatalyzed cell death pathway. Limnol Oceanogr 49:997-1005

Bidle KD, Falkowski PG (2004) Cell death in planktonic, photosynthetic microorganisms. Nat Rev Microbiol 2:643-655

Boyd PW, Aiken J, Kolber Z (1997) Comparison of radiocarbon and fluorescence based (pump and probe) measurements of phytoplankton photosynthetic characteristics in the Northeast Atlantic Ocean. Mar Ecol Prog Ser 149: 215-226

Crippen RW, Perrier JJ (1974) The use of neutral red and Evans blue for live-dead determinations of marine plankton. Stain Technol 40:97-104

Cullen JJ, Davis RF (2003) The blank can make a big difference in oceanographic measurements. Limnol Oceanogr
Bull 12:29-35

Cullen JJ, Renger EH (1979) Continuous measurement of the DCMU-induced fluoresence response of natural phytoplankon populations. Mar Biol 53:13-20

Dijkman NA, Kromkamp JC (2006) Photosynthetic characteristics of the phytoplankton in the Scheldt estuary: community and single-cell fluorescence measurements. Eur J Phycol 41:425-434

$>$ Doucette GJ, Fryxell GA (1983) Thalassiosira antarctica: vegetative and resting stage chemical composition of an icerelated marine diatom. Mar Biol 78:1-6

Falkowski PG, Barber RT, Smetacek V (1998) Biogeochemical controls and feedbacks on ocean primary production. Science 281:200-206

Franklin DJ, Berges JA (2004) Mortality in cultures of the dinoflagellate Amphidinium carterae during culture senescence and darkness. Proc R Soc Lond B Biol Sci 271: 2099-2107

Franklin DJ, Brussaard CPD, Berges JA (2006) What is the role and nature of programmed cell death in phytoplankton ecology? Eur J Phycol 41:1-14

Geider RJ, LaRoche J, Greene RM, Olaizola M (1993) Response of the photosynthetic apparatus of Phaeodactylum tricornutum (bacillariophyceae) to nitrate, phosphate, or iron starvation. J Phycol 29:755-766

Gervais F, Riebesell U, Gorbunov MY (2002) Changes in primary productivity and chlorophyll $a$ in response to iron fertilization in the Southern Polar Frontal Zone. Limnol Oceanogr 47:1324-1335

Greene RM, Kolber ZS, Swift DG, Tindale NW, Falkowski PG (1994) Physiological limitation of phytoplankton photosynthesis in the eastern equatorial Pacific determined from variability in the quantum yield of fluorescence. Limnol Oceanogr 39:1061-1074

> Hartig P, Wolfstein K, Lippemeier S, Colijn F (1998) Photosynthetic activity of natural microphytobenthos populations measured by fluorescence (PAM) and ${ }^{14} \mathrm{C}$-tracer methods: a comparison. Mar Ecol Prog Ser 166:53-62

Hayakawa M, Suzuki K, Saito H, Takahashi K, Ito SI (2008) Differences in cell viabilities of phytoplankton between spring and late summer in the northwest pacific Ocean. J Exp Mar Biol Ecol 360:63-70

Kolber Z, Falkowski PG (1993) Use of active fluorescence to estimate phytoplankton photosynthesis in situ. Limnol Oceanogr 38:1646-1665

> Kolber ZS, Van Dover CL, Niederman RA, Falkowski PG (2000) Bacterial photosynthesis in surface waters of the open ocean. Nature 407:177-179

- Kromkamp J, Forster R (2003) The use of fluorescence measurements in aquatic ecosystems: differences between multiple and single turnover measuring protocols and suggested terminology. Eur J Phycol 38:103-112

> Laroche J, Geider RJ, Graziano LM, Murray H, Lewis K (1993) Induction of specific proteins in eukaryotic algae grown under iron-, phosphorus-, or nitrogen-deficient conditions. J Phycol 29:767-777

Llabares M, Agustí S (2006) Picophytoplankton cell death induced by UV radiation: evidence for oceanic Atlantic communities. Limnol Oceanogr 51:21-29

> Marañón E, Behrenfeld MJ, González N, Mouriño B, Zubkov MV (2003) High variability of primary production in oligotrophic waters of the Atlantic Ocean: uncoupling from phytoplankton biomass and size structure. Mar Ecol Prog Ser 257:1-11

> McMinn A, Hesgeth EN (2004) Quantum yield and photosynthetic parameters of marine microalgae from the southern Arctic Ocean, Svalbard. J Mar Biol Assoc UK 84:865-871 Olaizola M, Geider RJ, Harrison WG, Graziano LM, Ferrari 
GM, Schlittenhardt PM (1996) Synoptic study of variations in the fluorescence-based maximum quantum efficiency of photosynthesis across the North Atlantic Ocean. Limnol Oceanogr 41:755-765

Pirker H, Pausz C, Stoderegger KE, Herndl GJ (2005) Simultaneous measurement of metabolic activity and membrane integrity in marine bacterioplankton determined by confocal laser-scanning microscopy. Aquat Microb Ecol 39:225-233

Sagert S, Forster RM, Feuerpfeil P, Schubert H (1997) Daily course of photosynthesis and photoinhibition in Chondrus crispus (Rhodophyta) from different shore levels. Eur J Phycol 32:363-371

Suggett DJ, MacIntyre HL, Geider RJ (2004) Evaluation of biophysical and optical determinations of light absorption by photosystem II in phytoplankton. Limnol Oceanogr

Editorial responsibility: Rodney Forster,

Lowestoft, UK
Methods 2:316-332

van Boekel WHM, Hansen FC, Riegman R, Bak RPM (1992) Lysis-induced decline of a Phaeocystis spring bloom and coupling with the microbial food web. Mar Ecol Prog Ser 81:269-276

Veldhuis MJW, Cucci TL, Sieracki ME (1997) Cellular DNA content of marine phytoplankton using two new fluorochromes: taxonomic and ecological implications. J Phycol 33:527-541

Veldhuis MJW, Kraay GW, Timmermans KR (2001) Cell death in phytoplankton: correlation between changes in membrane permeability, photosynthetic activity, pigmentation and growth. Eur J Phycol 36:167-177

Villareal TA (2004) Single-cell pulse amplitude modulation fluorescence measurements of the giant diatom Ethmodiscus (bacillariophyceae). J Phycol 40:1052-1061

Submitted: August 20, 2008; Accepted: February 9, 2009 Proofs received from author(s): April 20, 2009 